DEPÓSITO LEGAL ZU2020000153

Esta publicación científica en formato digital

es continuidad de la revista impresa

ISSN 0041-8811

E-ISSN 2665-0428

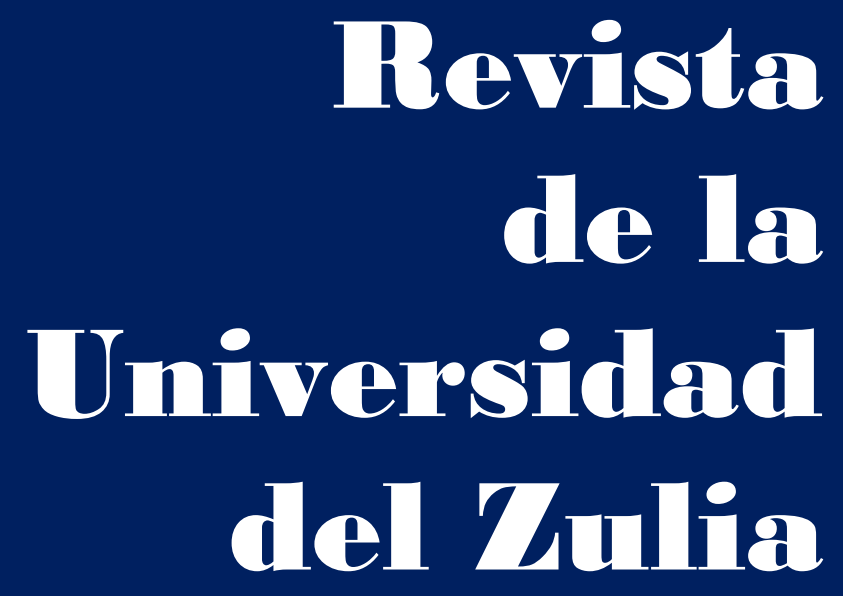

Fundada en 1947

por el Dr. Jesús Emrique Lossada

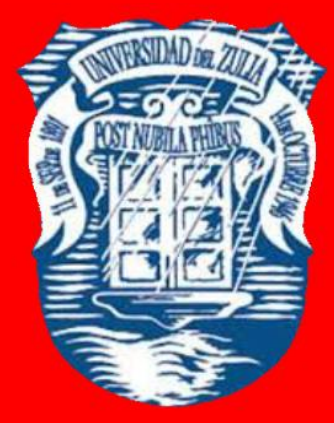

Ciencias

Sociales

y Arte

Año $12 \quad N^{\circ} 34$

Septiembre - Diciembre 2021

Tercera Época

Maracaibo-Veneruela 


\title{
The role of transnational companies in the reality of the new world
}

\author{
Anton A. Evsuykov *
}

\begin{abstract}
The purpose of the study is to analyze the problem of determining the status of transnational corporations in the system of global governance, in revealing the transition of transnational corporations from an economic subject of international relations to understanding it as a political actor in the system of international relations. The article covers a range of issues related to attempts to regulate foreign TNCs by national states, It also touches upon the issue of changing the positions of leading TNCs in the ratings compiled by authoritative publications over the past decade, an analysis of the influence of transnational corporations as non-state actors in world politics is carried out. Research methodology. Analysis of published survey reports of international organizations and individual leading transnational corporations. One of the most pressing issues in the study of the role and place of transnational corporations in world politics is the problem of determining the status of transnational corporations in the global governance system. As a result, we find that transnational corporations act in the global governance system as tools and as institutions, which requires the development of new scientific approaches that reflect the dynamics of the introduction of these actors into the system of world politics.
\end{abstract}

KEY WORDS: transnational corporations; business management; international relations; Political science; Economics; international politics; international security; international cooperation; Globalization.

* Postgraduate student for the Federal State Autonomous Educational Institution of Higher Education "Russian Peoples' Friendship University", Moscow, Russia. ORCID: https://orcid.org/0000-0001-9599-1465. SPIN: 3747-3590. Author ID: 873469. E-mail: 3448149@gmail.com 


\section{El papel de las empresas transnacionales en la realidad del nuevo mundo}

RESUMEN

El objetivo del estudio es analizar el estatus de las empresas transnacionales en el sistema de gobernanza global, donde se observa la transición de las empresas transnacionales de un sujeto económico de las relaciones internacionales a un actor político en el sistema de relaciones internacionales. El artículo abarca una serie de cuestiones relacionadas con los intentos de regular las empresas trasnacionales extranjeras por parte de los Estados nacionales. Metodología de investigación. Análisis de informes de encuestas publicados de organizaciones internacionales y empresas transnacionales líderes individuales. Uno de los temas más urgentes en el estudio del papel y el lugar de las corporaciones transnacionales en la política mundial es el problema de determinar el estatus de las corporaciones transnacionales en el sistema de gobernanza global. Como resultado, encontramos que las empresas transnacionales actúan en el sistema de gobernanza global como herramientas y como instituciones, lo que requiere el desarrollo de nuevos enfoques científicos que reflejen la dinámica de la introducción de estos actores en el sistema de la política mundial.

PALABRAS CLAVE: empresas transnacionales; gestión empresarial; relaciones internacionales; Ciencia política; Economía; política internacional; seguridad internacional; cooperación internacional; Globalización.

\section{Introduction}

The relevance of this topic is due, firstly, to the growing role of transnational corporations (TNCs) in the development of world geopolitical and geo-civilizational phenomena and processes in order to realize the interests of the world's leading actors, and secondly, to the aggravation of the competitive geopolitical struggle for the influence of TNCs on the economic development of national economies and the security of host countries.

The purpose of the study is to analyze the problem of determining the status of TNCs in the system of global governance, in revealing the transition of TNCs from an economic subject of international relations to understanding it as a political actor in the system of international relations.

The objectives of the study were: a brief analysis of the activities and characteristics of transnational non-state actors; consideration of the activities of TNCs from the point of view of their own interests both as instruments and as institutions for influencing world 
REVISTA DE LA UNIVERSIDAD DEL ZULIA. 3época. Año $12 \mathrm{~N}^{\circ}$ 34, 2021 Anton A. Evsuykov // The role of transnational companies in the reality of the new world, 97-105

processes; substantiation of the massive "invasion" of TNCs into world politics, under the influence of which the role of TNCs as a subject of the world political process is changing. One of the most pointed issues in the research of the role and place of TNCs in world politics is the problem of determining the status of TNCs in the global governance system. Many scientists and experts specializing in the research of the problems and perspective of global governance argue that the world, lead by globalization, is moving towards precisely this form of regulation of relations between all participants in world political and economic relations; at the same time, TNCs act in the system of global governance both as instruments and as institutions.

\section{Methodology}

The research methodology is based on the use of: a systemic method that allows a multifactorial and comprehensive study of the place, role and interests of TNCs as an international actor realizing their interests in the geopolitical space; the method of geopolitical analysis, which substantively studies the geopolitical "cut" of international relations, geopolitical processes, conflicts, fundamental value foundations, "internal springs" of events, phenomena occurring at the borders of contacting states as a result of the activities of TNCs; and also on the use of the spatial-contextual method, which implies that the phenomenon develops and is studied not by itself, but in the context of the sequential development of processes separated in time and space, which allows a deeper understanding of the phenomenon under study, the causes of the events being studied, with the possibility of a deeper penetration into their essence and the formation of forecasts for the development of processes.

\section{Results and Discussion}

One of the most pressing issues in the study of the role and place of TNCs in world politics is the problem of determining the status of TNCs in the global governance system. Many scholars and experts specializing in the study of the problems and prospects of global governance argue that the world, guided by globalization, is moving towards precisely this form of regulation of relations between all participants in world political and economic relations; at the same time, TNCs act in the global governance system both as instruments and as institutions. A wide range of actors is involved in global governance, there is a greater 
REVISTA DE LA UNIVERSIDAD DEL ZULIA. 3época. Año $12 \mathrm{~N}^{\circ}$ 34, 2021 Anton A. Evsuykov // The role of transnational companies in the reality of the new world, 97-105 DOI: http://dx.doi.org/10.46925//rdluz.34.07

number of connections and interactions, all types of political strategies known to mankind are applied. An increasing number of new actors, the overwhelming majority of whom do not belong to states and IGIO that do not have sovereignty and international legal personality in its traditional sense. The activity of non-state actors, to which TNCs can be ranked, often leads to the fact that such areas as social, economic, industrial and security spheres "leave" the state. which have always originally belonged to him. As Ilyin noted, when there is a general inability of traditional actors (meaning the state) of international relations to stabilize the situation on a global scale and develop solutions with an adequate response to modern challenges and threats, "non-state actors begin to interfere in this process, striving to intercept the functions of global regulation and management. from nation-states and international organizations" (Ilyin, 2011). Possessing significant resources of influence on world politics (not only material ones), transnational non-state actors (such as TNCs and IGIOs) generate "non-systemic phenomena" in it, which is facilitated by the increasing transparency of borders and the erosion of the sovereignty of national states, indirectly associated with global world political processes. Having a highly dynamic scientific, production and market potential, TNCs operating through their branches and subsidiaries in many countries have formed the so-called. "Think tanks" that form a monetary and financial strategy that is beneficial for them, contributing to their dynamic accelerated development (Shurahbil, 2017). As a result, according to Kenichi Ohmae, the state in the modern world is retreating, freeing up the field not only for capital, but also for the political activity of such subjects as "individuals, firms and markets" (Ohmae K, 1990). And TNCs began to play an important role in this process. Do not forget that TNCs, pursuing their own interests and acting within the framework of their own strategies, try to bypass local legislation and often ignore the interests of the host country, which becomes the cause of contradictions between TNCs and the governments of host states.

At the present stage of development, TNCs begin to function like states. In this regard, it is interesting that, for example, the American corporation IBM has its own diplomatic personnel to establish business relations with potential clients (Krivenko, 2016). Indeed, the influence of TNCs on global processes is very great. The ratings of the largest TNCs, regularly conducted by the American business magazine Forbes, have demonstrated their influence on the current world position of countries. So, in 2016, the magazine published a rating of the 
REVISTA DE LA UNIVERSIDAD DEL ZULIA. 3época. Año $12 \mathrm{~N}^{\circ}$ 34, 2021 Anton A. Evsuykov // The role of transnational companies in the reality of the new world, 97-105 DOI: http://dx.doi.org/10.46925//rdluz.34.07

two thousand largest and most influential companies in the world. In this rating "companies from 62 countries of the world were represented. Including 515 companies - from the USA, 210 - from Japan, 113 - from China, 56 - from India, 62 - from Canada” (Krivenko, 2016). According to the Forbes rating, "the most influential transnational company in the world at that time was the American bank JP Morgan Chase. The top five also included General Electric, Bank of America, the American oil and gas corporation Exxon Mobil and the Chinese bank ICBC"(Corporations that rule the world, 2011). As a result, a new criterion for assessing state sovereignty arose - efficiency (by the way, the same criterion is the main one in assessing the activities of TNCs). But, already in 2020, according to the rating, the TNCs of China took the leading positions, ahead of the US corporations (Ranking of the world's largest technology companies, 2018).

The place occupied by TNCs in the rating and the influence of TNCs on the world market are interconnected, which also plays a significant role in the status of a state in international relations. As a result of the activities of TNCs, the import of institutions is carried out - those "rules of the game" (labor and antitrust laws, principles of taxation, contracting practices, etc.) that have formed in developed countries. TNCs objectively increase the influence of the countries exporting capital on the countries importing them. For example, German firms in the 1990s subjugated almost all Czech business, as a result of which, according to some experts, Germany established much more effective control over the Czech economy than in 1938-1944, when Czechoslovakia was seized by Nazi Germany. The economy of Mexico and many other countries of Latin America is controlled by American capital in a similar way.

Corporations have a number of objectively important characteristics as members of international relations. These include the presence of territories for the implementation of activities, the existence of subdivisions and branches for the sale of products without customs duties, as well as the involved human, natural, scientific resources of foreign states (Shurahbil, 2017; Mikryukov, 2021). That is, at the present stage of development, TNCs occupy positions of active participants in the international division of labor and cooperation and distribute world resources.

Assessment of the influence of TNCs on the economic development of national economies and the security of host countries is currently rather ambiguous. On the one hand, 
REVISTA DE LA UNIVERSIDAD DEL ZULIA. 3é época. Año $12 \mathrm{~N}^{\circ}$ 34, 2021

Anton A. Evsuykov // The role of transnational companies in the reality of the new world, 97-105

DOI: http://dx.doi.org/10.46925//rdluz.34.07

TNCs are viewed as the main structural element of the economy of most countries, the leading force of their economies, economic processes are associated with their motives to defend their interests. On the other hand, their activities can provoke negative consequences for the political regime of states. In the scientific literature, there is also a purely negative attitude towards TNCs and the role they play in world and national politics. So, for example, back in the 90s, RI Zimenkov noted that TNCs negatively affect the economy of the third world countries and their activities lead to the destruction of political mechanisms operating in society, as well as to the loss of the state's main functions in the field economic regulation (Zimenkov, 1990).

At present, one can notice that he is not only paying attention to the states of the "third world". sanctions policy pursued by the United States and European countries, but it is in solidarity with the activities of TNCs. Transnational corporations, as noted by A.I. Podberezkin, "will strive to exert more influence on the conduct of the government course of their states and use state resources to achieve their goals in the international arena; at the same time, an increase in the total number of TNCs and their resources of influence in key countries of the world will most likely lead to a mutual balancing of their conflicting aspirations "; that is why "the degree of influence of TNCs on the politics of leading states will depend on their ability to create coalitions of interests with the participation of other TNCs." (Podberezkina and Aleksandrova, 2016). This is a balanced, conservative point of view on the role of TNCs in world politics and the nature of their influence on the sovereign policy of national states. This point of view can hardly be disputed - for criticism it seems to be very cautious. At the same time, outside the framework of this position, there are qualitative changes taking place in the entire world politics as a whole: under the influence of the massive "invasion" of TNCs into world politics, the role of TNCs as a subject of the world political process is changing.

A very clear example of significant problems in world politics and in the free trade market is associated with the sanctions policy of the United States and the Chinese company Huawei. As a global company, Huawei is opposed to protectionism and prioritizes business compliance above its own commercial and national interests. The growing ambitions of China, supported by the growing importance of digitalization, (Kayin Fu, 2020) which lays 
REVISTA DE LA UNIVERSIDAD DEL ZULIA. 3é época. Año $12 \mathrm{~N}^{\circ}$ 34, 2021

Anton A. Evsuykov // The role of transnational companies in the reality of the new world, 97-105

the foundations of the intellectual world, is of concern primarily to the United States, which sees in China not only a potential competitor, but also a threat to its national security.

Politicians in the United States, regardless of their views on domestic issues, agree that China should not be given priority. Regardless of who is in the White House, China's containment strategy will not change significantly. Therefore, the introduction of the sanctions regime is de facto the use of brute, unlimited force, which should break the Chinese corporation. This means that this is not a matter of Huawei's agreements with anyone, but a big problem in world politics. A state of emergency was introduced by presidential decree of May 16, 2019, which allows companies to be included in the list of national threats. On the same day, the US Department of Commerce listed both Huawei and all of its subsidiaries. The blackmail pretext used to attack Huawei is serious, but any accusation requires at least minimal evidence, no evidence has been presented. As a result, even the closest allies of the United States, for example, the United Kingdom and Germany, did not abandon Huawei in their plans to deploy $5 \mathrm{G}$ networks, but only tightened conditions and focused on security.

On August 2, 2017, the President of the United States signed the Countering America's Adversaries Through Sanctions Act (H.R. 3364), approved by the US Senate and House of Representatives. The law is a political document aimed at strengthening the sanctions regime against Iran, Russia and North Korea and limiting the powers of the US President to lift sanctions that have already entered into force without the approval of the US Congress.

As far as the Russian Federation is concerned, the document contains an assessment of Russia's foreign policy and a list of political, military and economic countermeasures aimed at destabilizing the Russian economy and putting pressure on the functioning of the Russian fuel and energy complex. The introduction of the sanctions restrictions regime has set new challenges for the current and long-term development for the key Russian oil and gas companies.

\section{Conclusion}

Summing up, we can conclude that the global competitive confrontation is escalating in the field of international relations, threatening peace, stability and international security, which in a certain way leaves an imprint on the role and political significance of TNCs. TNCs need to expand their political influence and their own political space, it is pointless to 
REVISTA DE LA UNIVERSIDAD DEL ZULIA. 3é época. Año $12 \mathrm{~N}^{\circ}$ 34, 2021 Anton A. Evsuykov // The role of transnational companies in the reality of the new world, 97-105

restrain them in this movement. Meanwhile, the field of world politics is occupied by traditional actors - nation-states, which are wary of the invasion of their sphere by non-state actors, in particular, such as TNCs. However, this does not stop TNCs: in their rivalry with nation-states for spheres of influence, they give rise to such a phenomenon as "privatization of world politics", which, by its very existence, completely changes the established ideas about the role of traditional and non-traditional actors in the global political process. The study of the role and place of TNCs in world politics requires the development of new scientific approaches that reflect the high dynamics of the implementation of these actors outside of sovereignty into the system of relations between states and interstate entities.

\section{Acknowledgment}

PhD Antcev Georgii Vladimirovich Radar-MMS.

\section{References}

Corporations that rule the world. 201l. In: http://rb.ru/article/korporatsii-kotorye-pravyatmirom/6756067.html (Date of access 10/12/2018).

Ilyin I.V. (2011). Globalistics in the context of political processes. Diss. ... doct. sciences. Moscow: Moscow State University.

Kayin Fu (2020), Research of Huawei's digital marketing strategy. Economic Science and Practice: Proceedings of the VIII Intern. scientific. conf. (Krasnodar, July 2020), Krasnodar: Novatsiya, p. 16-20. In: https://moluch.ru/conf/econ/archive/376/15779/ (date of access: 24.02.2021).

Krivenko, K.V. (2016). Possibilities of increasing the role of transnational corporations in the structure of the world economy, Young Scientist, No. 27 (131), p. 408-41l. In: https://moluch.ru/archive/131/36571/ (date of access: 12.02.2021).

Lebedeva M.M. (2008). Privatization of world politics: local actions - global results. ZAO Goldon-Bee Moscow.

Mikryukov, V. (2021). Gaps and analogies in the formation of registered capital of limited liability and joint-stock companies. Cuestiones Politicas, 39(69), 237-260. https://doi.org/10.46398/cuestpol.3969.14

Ohmae K. (1990). The Bordless World - Power and the Strategy in the Interlinked Economy. Fontana. 
REVISTA DE LA UNIVERSIDAD DEL ZULIA. $3^{a}$ época. Año $12 \mathrm{~N}^{\circ}$ 34, 2021 Anton A. Evsuykov // The role of transnational companies in the reality of the new world, 97-105 DOI: http://dx.doi.org/10.46925//rdluz.34.07

Podberezkina A.I., Aleksandrova M.V. (2016). Strategic forecasting of international relations: count. Monograph. MGIMO (un-t) Ministry of Foreign Affairs of the Russian Federation, Center for Military-Political Research. Moscow: MGIMO-University.

Ranking of the world's largest technology companies in 2018. Official web-site "Forbes". In: https:/forbes.kz/leader/reyting krupneyshih tehnologicheskih kompaniy mira 2018. (Date of access 06.01.2021)

Shurahbil M. A. (2017). The place and role of transnational corporations in the modern world economy, Young scientist, No. ll (145), p. 183-186. In: https://moluch.ru/archive/145/40719/ (date of access: 12.02.2021).

Zimenkov R.I. (1990). Conquistadors of the 20th century. Expansion of transnational corporations in developing countries. Moscow: Politizdat. 